\title{
Die Suid-Afrikaanse vrou in landsverdediging - agtergrond en perspektief
}

\author{
Lt kdr E.M. Meyers*
}

In the history of South Africa its women always had some role to play in the defence of the country. Women were engaged in military activities even before the institution of the Union Defence Force in 1912. The role of the "Voortrekker" women and also the role of women during the Second War of Independence is referred to as well as their role during both World Wars.

The Women's Auxiliary Services originated in 1939 and they played a major role during both war and post war periods. Important to note is the role that the Army Women's College at George played in the renewed militarization of women.

The present-day training and utilization of women in the SADF as well as the question of National Service for women are dealt with including detailed arguments for and against the latter.

Only one conclusion can be arrived at after having studied all the material and that is that women in uniform have definitely come to stay.

\section{Inleiding}

Die Suid-Afrikaanse vrou se aandeel in landsverdediging was tot onlangs beperk tot ' $n$ ondersteunende rol gedurende oorlogsituasies. Tog was vroue reeds voor die stigting van die Unieverdedigingsmag in 1912 by militêre aktiwiteite betrokke, hoewel alleenlik in 'n ondersteunende hoedanigheid. Gedurende die Tweede Vryheidsoorlog het Boerevroue byvoorbeeld die kommando's gevolg waarin hulle mans gedien het en vir hulle gekook, herstelwerk verrig en ook as verpleegsters diens gedoen. In enkele gevalle het hulle self die wapen opgeneem en aan veldslae deelgeneem.

Die Twee Wêreldoorloë het die vrou die geleentheid gebied om in 'n groter mate militêr betrokke te raak en haarself as onontbeerlik in landsverdediging in oorlogstoestande te bewys. Gedurende die Eerste Wêreldoorlog het sy net as verpleegster op die slagveld en aan die tuisfront gedien. Hierteenoor het haar militêre bydrae in die Tweede Wêreldoorlog, afgesien van die Militêre Verplegingsdiens uitgekring tot die onderskeie Vrouehulpdienste.

'n Algemene afplatting in die vraag na vroulike militêre personeel in die Weermag het die naoorlogse periode gekenmerk en die vrou in uniform het tydelik van die toneel verdwyn.

Die jaar 1970 was 'n mylpaal vir die vrou in die Suid-Afrikaanse Weermag, aangesien vroue weer vir die eerste keer vir die Staande Mag ge- werf is. $\mathrm{Na}$ ' $\mathrm{n}$ kwarteeu het die vrou weer uniform gedra.

Met die hertoetrede van vroulike militêre personeel moes konsensus oor verskeie aangeleenthede wat die vrou ten nouste raak, bereik word. 'n Algemene hanteringsbeleid tov die vrou in uniform moes opgestel word. Hierin moes sake uiteengesit word soos vereistes, opleiding, loopbaanvooruitsigte, indiensnemingsvoorwaardes, bevordering, gedrags- en dissiplinêre kodes, akkommodasie asook die profiel van die vrou in uniform. Oplossings moes gevind word vir kwelvrae soos die instelling van diensplig vir vroue, haar posisie tov die gevegsituasie en haar toekomsverwagtinge.

Die bydrae van die vrou in landsverdediging en meer spesifiek haar rol en plek in die Suid-Afrikaanse Weermag kan nie na regte geëvalueer word tensy dit vanuit ' $n$ historiese perspektief benader word nie.

\section{Voortrekkervroue}

Daar bestaan goeie voorbeelde van Voortrekkervroue wat hulle mans en seuns bygestaan het in gevegte teen swart stamme onder meer by Bloedrivier (16 Des 1838) en Vegkop (Okt 1836). By sulke geleenthede het vroue gewoonlik gehelp $\mathrm{om}$ gewere te laai. $\mathrm{Na}$ ' $n$ lang geveg by Vegkop waarin die vroue en dogters die veertig vegtende mans bygestaan het, is die Matabeles op die vlug gejaag en is byna 500 dooies op die slagveld agtergelaat. 
Dit word vertel dat selfs kinders aktief betrokke was by die stryd teen die Zoeloes in Natal. Terwyl die assegaaie om hul gefluit het, moes die groter seuns help om te skiet, en die meisies hul moeders help om koeëls te giet en die gewere te laai. Die Voortrekkerdogters het selfs beurte gekry om snags by die kamp wag te staan.

\section{Tweede Vryheidsoorlog (1899-1902)}

Vroue het gedurende die Tweede Vryheidsoorlog op velerlei wyses bewys dat hulle 'n groter rol in landsverdediging wou speel. Meesal het vroue wat hul mans op kommando gevolg het, daar vir hulle gekook en gesorg, hoewel enkeles by wyse van uitsondering saam met die mans aan die geveg deelgeneem het.

Gewapende Afrikanervroue was volgens krygshistorikus C.M. Bakkes aktief in die loopgraafstryd betrokke tydens die Slag van Pietershoogte op 27 Februarie 1900 aan die Natalse front. Jeans meld in sy beskrywing van die vlootbrigade se deelname aan die stryd in Natal dat baie vroue en kinders in die loopgrawe gewond is. 'n Britse soldaat het aan sy vrou geskryf oor die vreesaanjaende gesig van meer as sestien gewapende vroue wat in die loopgrawe doodgeskiet is voordat hulle kans gehad het om terug te trek.

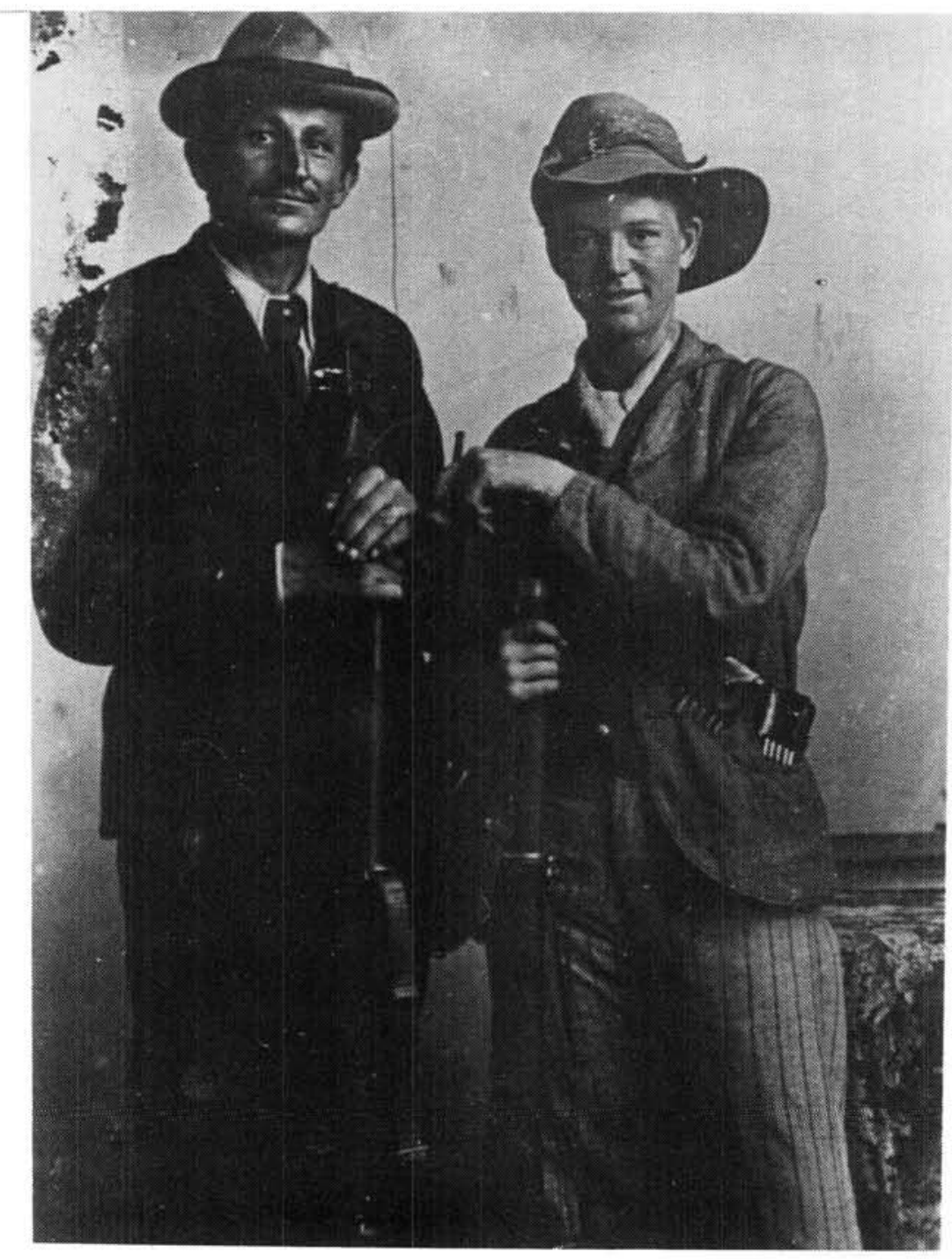

Helena Herbst Wagner (regs) wat drie maande lank op kommando was 
Bakkes noem die geval van 'n sekere Helena Herbst Wagner van Zeerust wat na die dood van haar baba haar man na die Natalse front sou gevolg het. Sy was gewapen en vermom in mansklere en toe sy hom nie kon vind nie, het sy by die Johannesburgse kommando aangesluit. Sonder om haar identiteit te openbaar, het sy aan die veldslae by Spioenkop, Vaalkrans en Pietershoogte deelgeneem.

Vooraanstaande Afrikanervroue is tydens die oorlog by die Boere se spioenasiediens betrek. Hulle was funksioneel in die ontvangs en deurgee van inligting ivm troepebewegings en van naamlyste van Boere wat as die sogenaamde National Scouts by die Britse magte aangesluit het. Die inligting is nie net aan die Boerehoofkwartier te velde deurgestuur nie, maar ' $n$ geheime kommunikasie is met President Kruger in Holland bewerkstellig. $\mathrm{Na}$ afloop van die oorlog het genl Louis Botha vir mev Van Warmelo, onder wie se leiding die geheime berigte versend is, bedank met dié woorde: " $U$ heeft gedaan en gewaagd wat ik zelf niet zou hebben aangedurf."

\section{Eerste Wêreldoorlog}

Gedurende die Eerste Wêreldoorlog het 328 verpleegsters die Suid-Afrikaanse magte vergesel in Oos-Afrika en Europa. 'n Vrywillige verplegingsdiens het in Augustus 1914 tot stand gekom en verpleegsters moes beskikbaar wees vir 'n tydperk van 6 maande of vir die duur van die vyandelikhede in Suid-Afrika afhangende van watter tydperk die langste was.

Na die Duitswes-veldtog en kort voor die vertrek van die verpleegsters na Europa, is die vrywillige verplegingsdiens ontbind en met ' $n$ permanente een vervang. Met die verslegting van die situasie aan die Wesfront is al hoe meer manlike verpleërs benodig vir diens aan die front en hul poste is deur verpleegsters gevul. In die lig van die toenemende behoefte aan verpleegsters wat oorsee benodig is, het baie verpleegsters op eie koste soontoe vertrek om diens te lewẹr.

\section{Tweede Wêreldoorlog}

Die getal Suid-Afrikaanse vroue wat in die Tweede Wêreldoorlog by die oorlogspoging betrokke was, is veel indrukwekkender as die met die Eerste Wêreldoorlog $\mathrm{nl}$ sowat 4000 verpleegsters en 21000 ander lede.

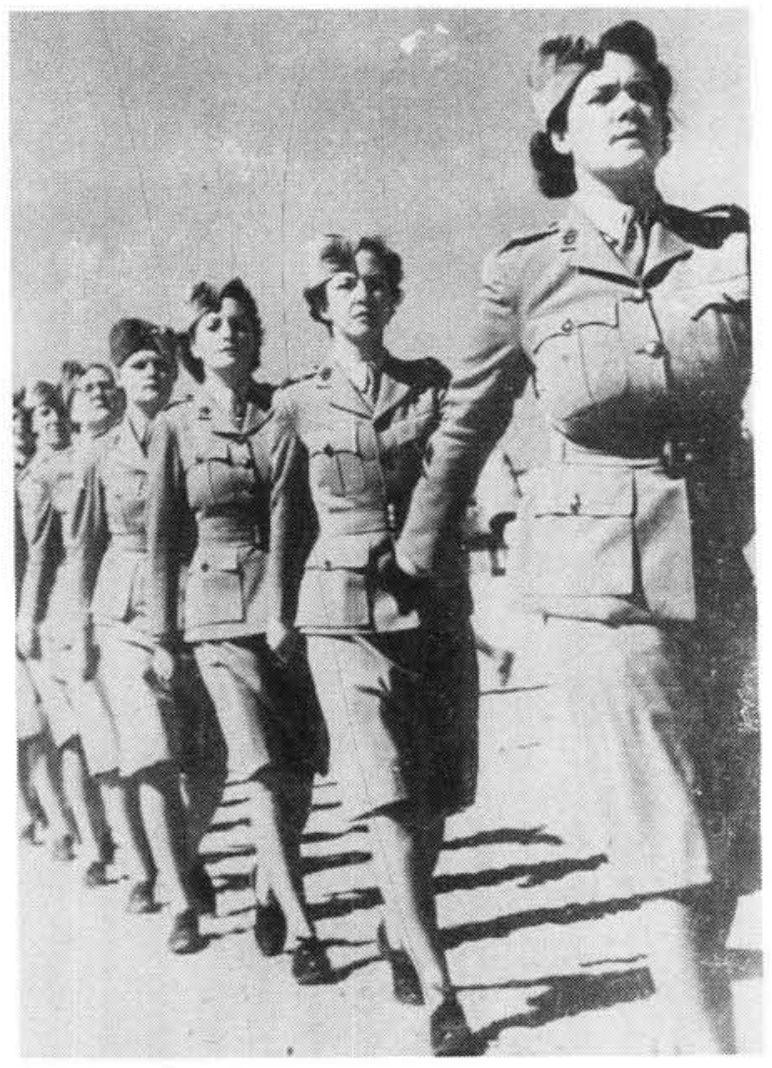

Lede van dle Vrouehulplugmag (VHLM) op parade in dle Midde-Ooste in 1942 (Foto van SAW Argief $n r 761004036$ )

\section{Verpleegsters}

Een van die eerste stappe in die uitbreiding van ' $n$ volskaalse verplegingsdiens was om die nodige opgeleide personeel by siviele hospitale te mobiliseer. Hoewel daar aanvanklik beoog is om net $10 \%$ van die opgeleide personeellede te trek, is $20 \%$ uiteindelik aangevra. Vroue wat sodoende betrek is, het aanvanklik net in OosAfrika diens gedoen, maar met die verloop van die oorlog is hulle dienste op ander fronte ook benodig.

Met die verloop van die oorlog het die Unieverdedigingsmagte na Noord-Afrika beweeg. Net vrywilligers is soontoe verplaas, aangesien die veldtog daar geweldige eise aan die vroue gestel het. Veldhospitale was blote tentsale met sandvloere en dikwels was daar geen badkamers of wasgeriewe nie behalwe ' $n$ paar krane wat om die hospitaal versprei was.

Verpleegsters wat na afloop van al die vyandelikhede na Suid-Afrika teruggekeer het, is deur oppermatrone Northard vir hulle optrede geloof: "To those who have sacrificed their lives in their efforts to save the lives of others; I find no words adequately pay tribute to such sacrifices". 


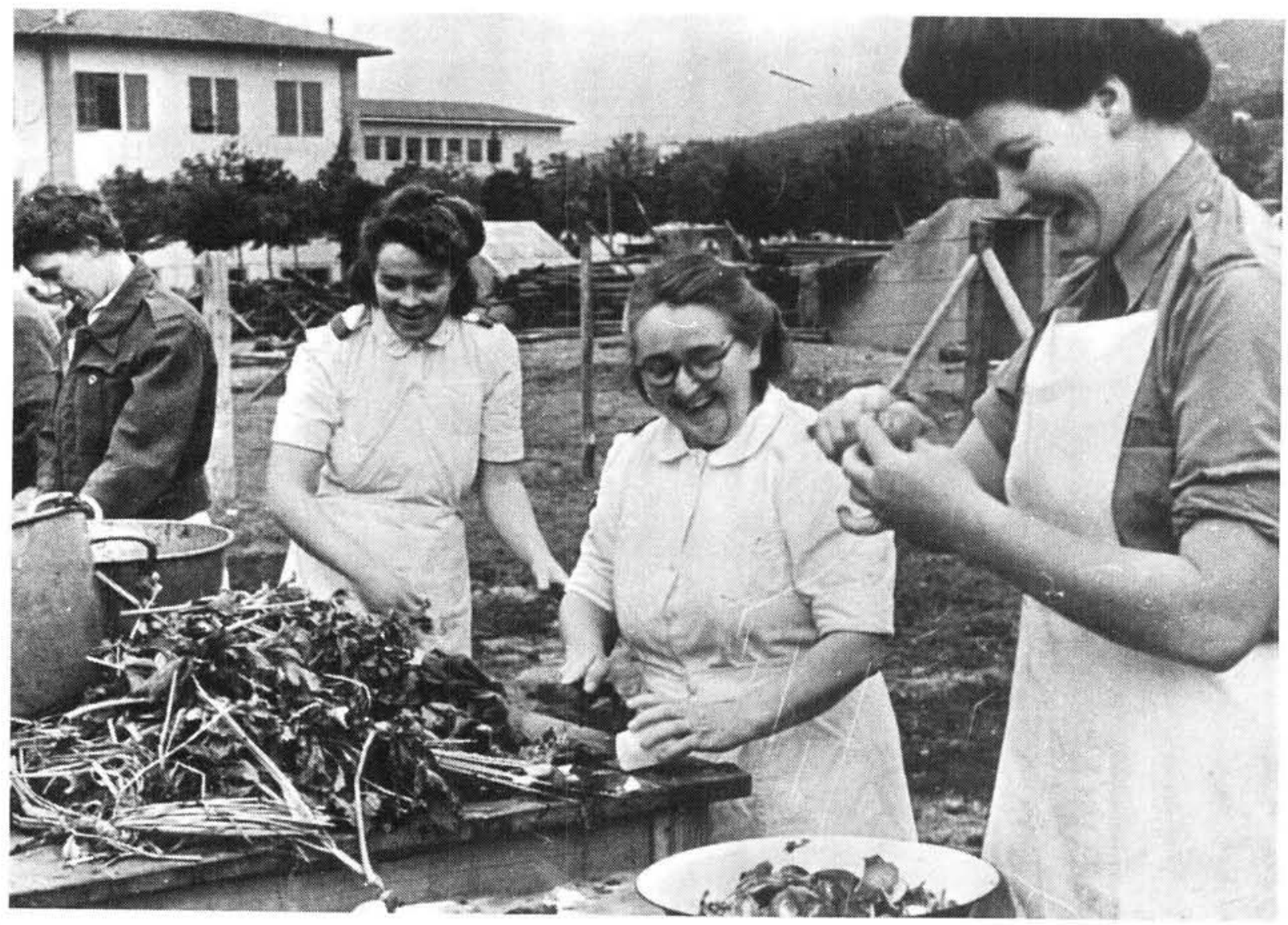

Diëetkundiges van die Vrouehulpleërdiens (VHLD) besig om 'n maaltyd voor te berei vir gewonde SA soldate in die Algemene Hospitaal in Italië in 1944. (Foto van SAW Argief $\mathrm{nr}$ 761001707)

\section{Hulpdienste}

\section{Algemeen}

In Suid-Afrika het die Vrouehulpdienste in 1939 voor die uitbreek van die Tweede Wêreldoorlog tot stand gekom. Kort na die stigting van die Suid-Afrikaanse Vrouehulpdiens (SAVHD) is die Vrouehulpverdedigingskorps (VHVK) gestig, bestaande uit die Vrouehulplandmag en die Vrouehulplugmag. In 1940 het die eerste vrouevrywilligers hulle by die Suid-Afrikaanse Weermag aangesluit. Alhoewel vroue aanvanklik net in die Leër en die Lugmag aangewend is, is hulle later ook in die Vloot opgeneem. In Julie 1943 was daar reeds 16262 vroue in diens en het die getalle uitgebrei tot 24427 aan die einde van die oorlog. Die vroue se georganiseerde poging tot landsdiens is deur die destydse Eerste Minister, genl J.C. Smuts, gesteun en dit was trouens hy wat die stigting van ' $n$ vroueleër gemagtig het.

Aanvanklik is die vrou in uniform hoofsaaklik in 'n ondersteunende rol aangewend. Honderde vroue is opgelei om in oorlogsfabrieke te werk, poskantore te beman, seiners te wees en vir soldate klere te maak en te brei. Kantienafdelings vir die soldate is deur hulle beman en rehabilitasie vir die gewonde soldate is deur hulle gedoen. Die vloot het vroue radiotegnici gehad en die lugmag het vroue as fotografiese assistente gebruik. In 1944 is die aanwending van vroue uitgebrei na verdedigingswapenstelsels waarin vroue opgelei is as operateurs in kus-artillerie instrumente en in radarstelsels.

Afsonderlike regulasies is vir elk van die Weermagsdele opgestel wat onder andere bepaal het dat: die kentekens en uniform van die onderskeie weermagsdele deur vroue gedra moes word; vroue dieselfde range as manlike lede sou dra; vroue onderworpe sou wees aan toepaslike gedragskodes en vroue deur vroue-offisiere verhoor moes word.

\section{Vrouehulpleërdiens}

Spoedig was dit duidelik dat 'n grootskaalse werwing van mans 'n dringende behoefte aan 


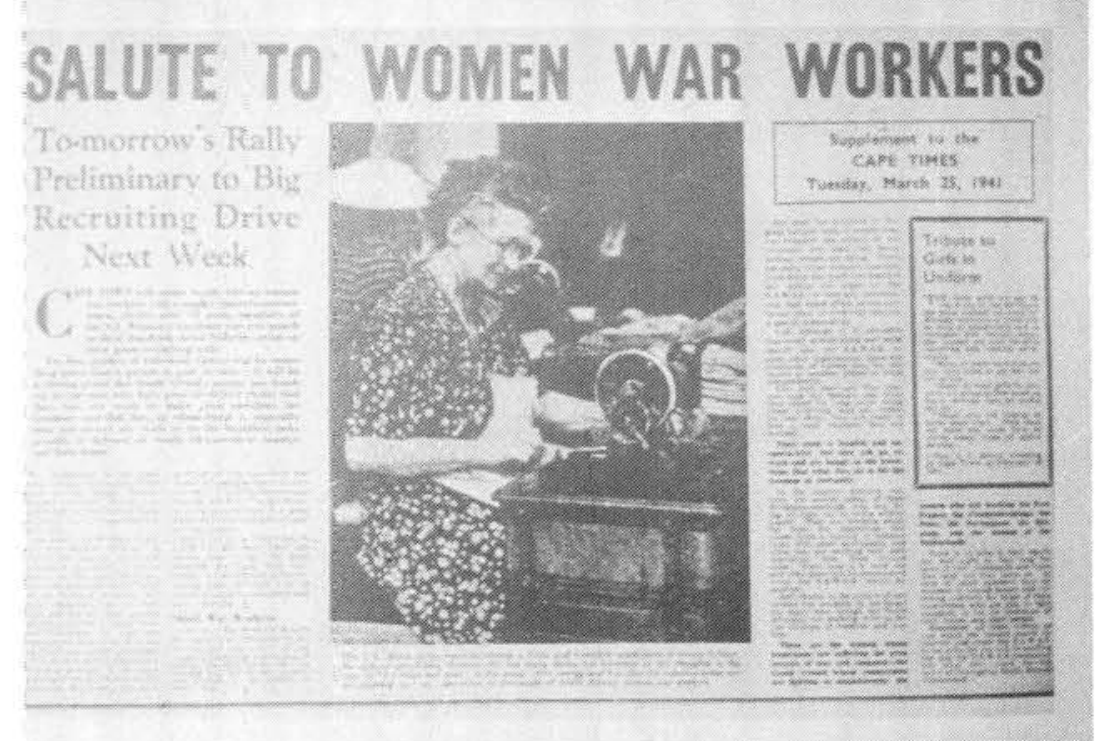

In Maart 1941 het die Vrouehulpdienste 'n werwingsveldtog geloods om meer vroue by die oorlogspoging te betrek

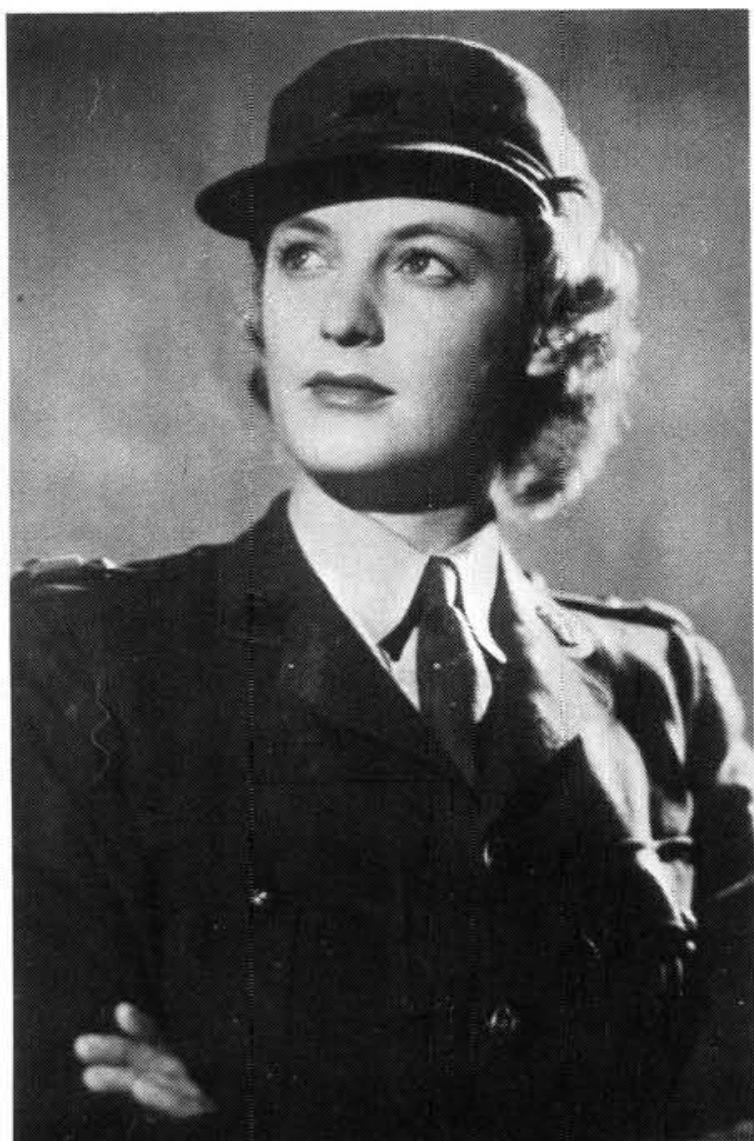

Lt Peggy Eaton, voorheen 'n sekretaresse van 'n groot maatskappy het in 1941 by die Vrouehulpleërdiens aangesluit vroueklerke tot gevolg sou hê om vakatures te vul. Om voorsiening vir hierdie moontlikheid te maak, het die Vrouehulpleërdiens tot stand gekom. Vroue in die leër het diens gedoen as motorbestuurders, klerke, seiners, rapportryers, kokke, radiografiste en kusartillerie spesialiste.

Die hulpleërdiens het eenhede dwarsdeur die Unie, in Nairobi en in die Midde-Ooste gehad. Nie net opgeleide vroue en spesialiste op sekere gebiede is verwelkom nie, maar vir die onopgeleide vrou het die hulpdiens ook plek gehad. Van al die vroue in die Leër het net een afdeling as't ware op die frontlinie geveg. Hierdie was vroue spesialiste wat as lede van die kus- en lugafweerartillerie diens gedoen het.

\section{Vrouehulplugmag}

Met die uitbreek van die oorlog op 3 September 1939 het die Suid-Afrikaanse Vrouelugvaartvereniging sy volle samewerking en dienste aan die regering aangebied. Nege maande later is Doreen Hooper, 'n vlieginstruktrise en voorsitster van die Vrouelugvaartvereniging, die eerste vrou wat vir voltydse diens opgeroep is. Sy is aangestel as direktrise van die SA Vrouehulplugmag met die rang van majoor.

In Februarie 1941 is op groot skaal met basiese opleiding vir vroue begin en in Junie het daar 35 kampe vir die Vrouehulplugmag (VHLM) bestaan. Sowat 75 soorte werk is tydens die oorlog deur hierdie vroue gedoen. Daar was onder meer kantoorwerk, fotografiese werk, telekom- 
munikasie-operatrises, die herbunkering van vliegtuie en verpakking van valskerms, radio operateurs, die herstel en soldeer van masjiendeeltjies, vragmotorbestuurders en spyseniers. Hoewel oorspronklik beoog is om net 1000 vroue op te lei, het 9143 vroue teen die einde van die oorlog as vrywilligers by die VHLM aangesluit.

Sedert die eerste vrou in September 1941 deur die VHLM na die Midde-Ooste gestuur is, het ' $n$ totaal van 232 lede van die VHLM daar in samewerking met die Royal Air Force oorlogsdiens gedoen. In Augustus 1944 is vyf offisiere van die VHLM na Italië oorgeplaas.

\section{Vrouehulpvlootdiens}

Die Vrouehulpvlootdiens het weens die deurlopende mannekrag tekort tot stand gekom. Deur vroue ondersteuningshulp te laat doen, kon meer mans vir seediens vrygestel word. Ten spyte van groot teenstand van Weermagsowerhede teen die skema, is die hulpvlootdiens op 9 Oktober 1943 gestig. Die maksimum vroue wat aangestel sou word, is op 281 bepaal. Werk wat vroue gedoen het, het gewissel van haweverdedigingsoperateurs tot klerklike werk. Net een pos vir ' $n$ vroueoffisier is vir die duur van die oorlog deur die VHVD geskep.

\section{Vrouehulpdiens op die tuisfront}

Vrywilliger vroue was voor die oorlog georganiseer in die Nasionale Diens wat met die uitbreek van die oorlog die SA Vrouehulpdiens geword het. In byna elke dorp in die Unie was ' $n$ tak van die Hulpdiens en selfs op die dunbevolkte platteland, het boervroue naaldwerk- en breigroepies georganiseer.

Belangrike werk wat deur die Hulpdiens gedoen is, was verpleging, vervoerwerk, brei, naaldwerk, kantienwerk en fondsinsameling vir die finansiering van welsynsdiens en oorlogsfondse. Bewaar- en kleuterskole vir soldate se kinders is opgerig en vroue wat diens gedoen het by die Hulpdienste se kinders is bedags opgepas. Die hulpdiens het verder by Militêre hospitale gehelp met die ontvangs en akkommodasie van gewonde soldate se besoekers. Vroue het leërposkantore in groot dorpe bestuur, boeke en tydskrifte versamel vir troepe en met die uitreiking van petrolkoepons gehelp. Die waardevolste diens wat deur die hulporganisasies verrig is, het gelê in die beïnvloeding van die publiek waardeur hulle gestadig en voortdurend die Unie se oorlogspoging bevorder het.

\section{Na-oorlogse periode}

Die beleid om vroue in militêre poste aan te

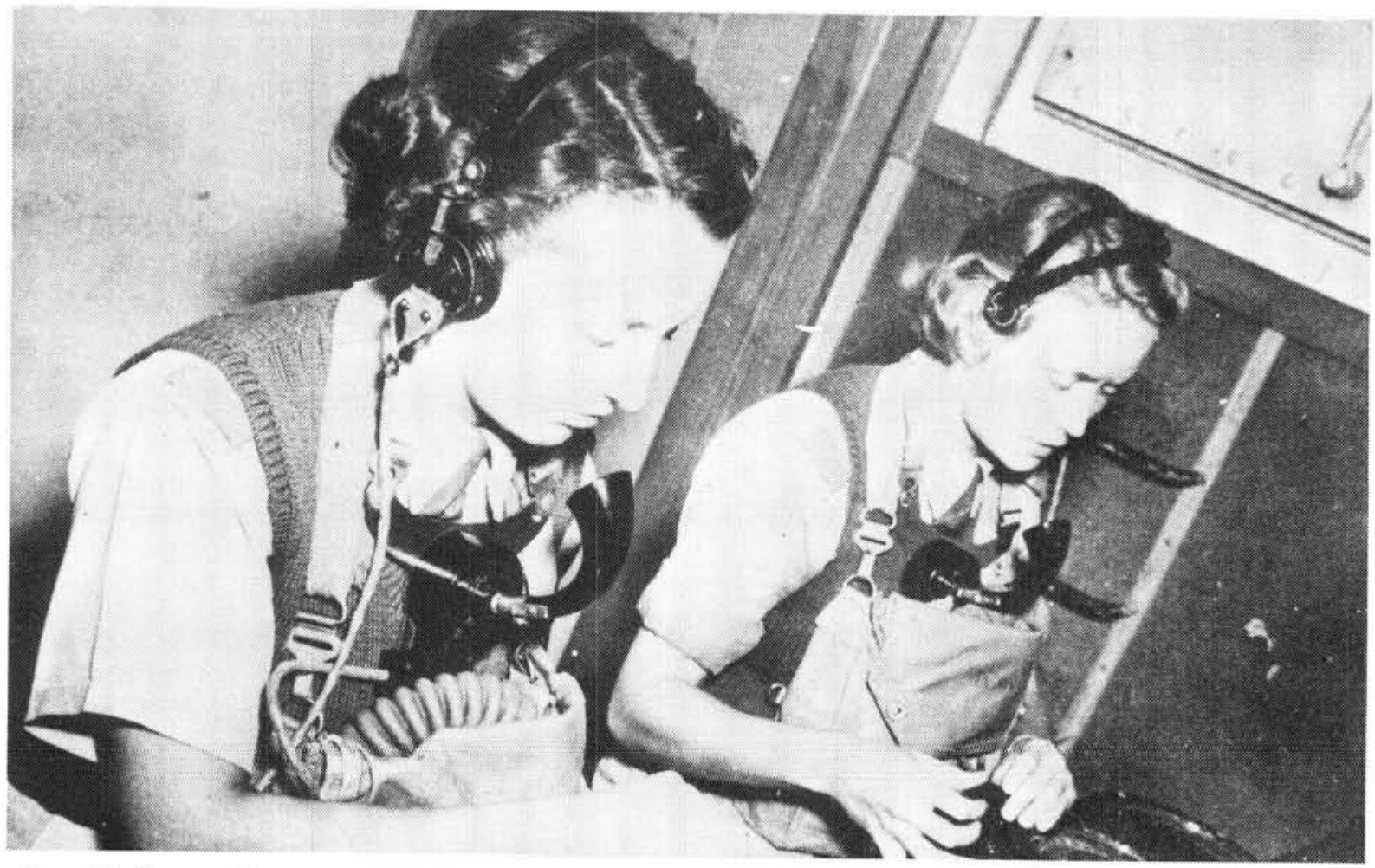

Kusartillerie spesialiste van die VHLD werk met afstandmetertoerusting in 'n ondergrondse bomvrye kamer. (Foto van SAW Argief $n r$ 7710015531) 
wend, het tot in 1949 voortgeduur toe die werwing van vroue vir die Vrouehulpverdedigingskorps gestaak is. Net vroue op die verplegingspersoneel van die Unieverdedigingsmag is behou.

In 1951 is die aanwending van die vrou in ' $\mathrm{n}$ militêre hoedanigheid weer oorweeg. Uit die beslissings wat gemaak is, was dit duidelik dat die aanwending van die vrou net in 'n oorlogsituasie gesien is. Afgesien van verpleegsters sou vroue nie in die aangesig van die vyand en buite die landsgrense aangewend word nie.

Vanaf 1952 tot en met 1963 met die verskyning van die Gordonverslag is vroue op ' $n$ beperkte skaal aangewend. In 1965 het 'n verdere komitee onder voorsitterskap van brig Mossop ' $n$ verslag uitgebring oor die vrou in die SA Weermag met ingrypende aanbevelings oor die aanwending van die vrou in die Staande Mag. Daar is onder meer besluit dat vroue tot die Staande Mag toegelaat moet word met inagneming van hul fisieke vermoëns. Daar is ook aanbeveel dat vroue teen bestaande mansposte aangewend moes word, die besoldiging van vroue dieselfde as die vir mans moes wees en dat vroue dieselfde rangsgesag as mans sou uitoefen.

\section{Leërvrouekollege}

Die Leër het die voortou geneem met die hernieude militarisering van die vrou toe die Burgerlike Beskermingskollege vir burgermagvrywilligers op George in 1971 gestig is. Vroue is vir 10 maande lank opgelei om hul leierspotensiaal te ontwikkel en te leer om in tye van rampe en noodtoestande die leiding in die burgerlike samelewing te kan neem. Kol Hilda Botha was die eerste vrouebevelvoerder van die kollege.

Voordat studente met hul opleiding kon begin, is hulle gekeur en hulle moes aan die volgende vereistes voldoen: hulle kon nie ouer as 22 jaar wees nie en moes gematrikuleerd, albei landstale magtig en ongetroud wees. Opleiding was heeltemal vrywillig. Teen die einde van 1972 het 265 burgermagvroue hul opleiding by die kollege voltooi en in April die daaropvolgende jaar het die eerste groep vroue wat uit die manskapsgeledere tot die SA Weermag toegetree en opleiding as kandidaat offisiere ontvang het, offisiersrange ontvang.

Aanvanklik is 150 vroue per jaar by die kollege in George nie net in tegnieke van burgerlike beskerming opgelei nie, maar ook in ' $n$ wye spek-

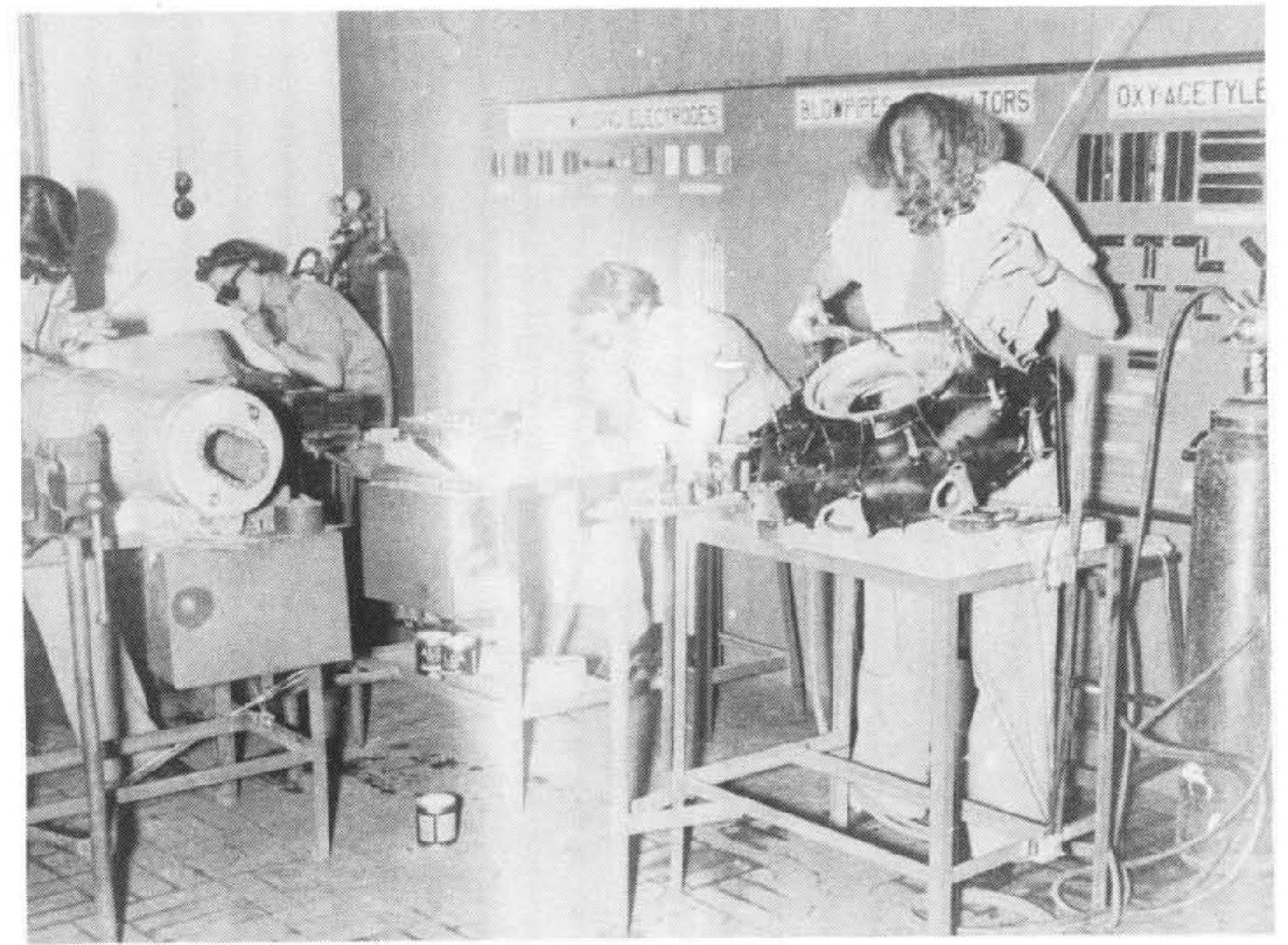

Tegnici van die VHLM besig met herstelwerk van vliegtuigonderdele (1942-1943) (Foto SAW Argief nr 781000861a) 
trum van militêre en algemene vakke. Die kollege se rol in die Weermag was sedert Januarie 1977 heelwat aktiewer met die stigting van die SA Leër Vrouekorps. Die kollege is omskep tot die SA Leërvrouekollege en heelwat meer vroue per jaar is vir die Staande Mag opgelei.

Sedert die stigting van die kollege tot 1977 was daar net een inname burgermagvroue per jaar. In 1977 het die situasie verander en was daar twee innames per jaar en is vroue na basiese-en vakopleiding uitgeplaas na Hoofkwartiere en eenhede.

Offisiersoriënteringskursusse vir gegradueerdes sowel as die juniorleiersoriënteringsfase vir die opleiding van instrukteurs en jong offisiere is vroeër by die kollege aangebied. Vanaf 1982 is alle Staandemag opleiding verskuif na Pretoria en tans word offisiersvorming en oriëntering by die SA Leërkollege saam met mans aangebied. Hoewel vroue nie doelbewus in die geveg aangewend word nie, is wapenopleiding deel van hul basiese kursus. Vir die eerste keer in vredestyd is vroue gewerf om in ' $n$ volwaardige professionele hoedanigheid in weermagsvertakkings opgeneem te word.

\section{Die sewentigerjare en daarna}

Met die toetrede van die Suid-Afrikaanse vrou tot die Staande Mag is ' $n$ nuwe era ingelui. Hoewel dit die beleid was om die vrou net by die tuisbasisse aan te wend, het sy al hoe meer uitdagende poste begin vul. Vlootvroue is aanvanklik net aangestel as liggaamlike opvoedingsinstruktrises, taktiese data operateurs en radio-operateurs, maar is later selfs in die vlootpolisie opgeneem. Lugmagvroue op hulle beurt het laat in die sewentigerjare verbaas met die totstandkoming van die eerste vroulike Burgermageskader no 114 .

Vroue in die SA Leër doen nie net klerklike werk nie, maar speel ' $n$ meer beduidende rol op die terrein van militêre intelligensie, as instrumente passers en as instrukteurs by die Pantser- en Hondeskool. Tog word vroue nie operasioneel in die poste aangewend nie.

Die toenemende rol wat deur vroulike militêre personeel in die SA Weermag sedert 1972 gespeel is, is ook in die SA Geneeskundige Diens se programme weerspieël. In Januarie 1979 het die SA Geneeskundige Diens se Opleidingsen-

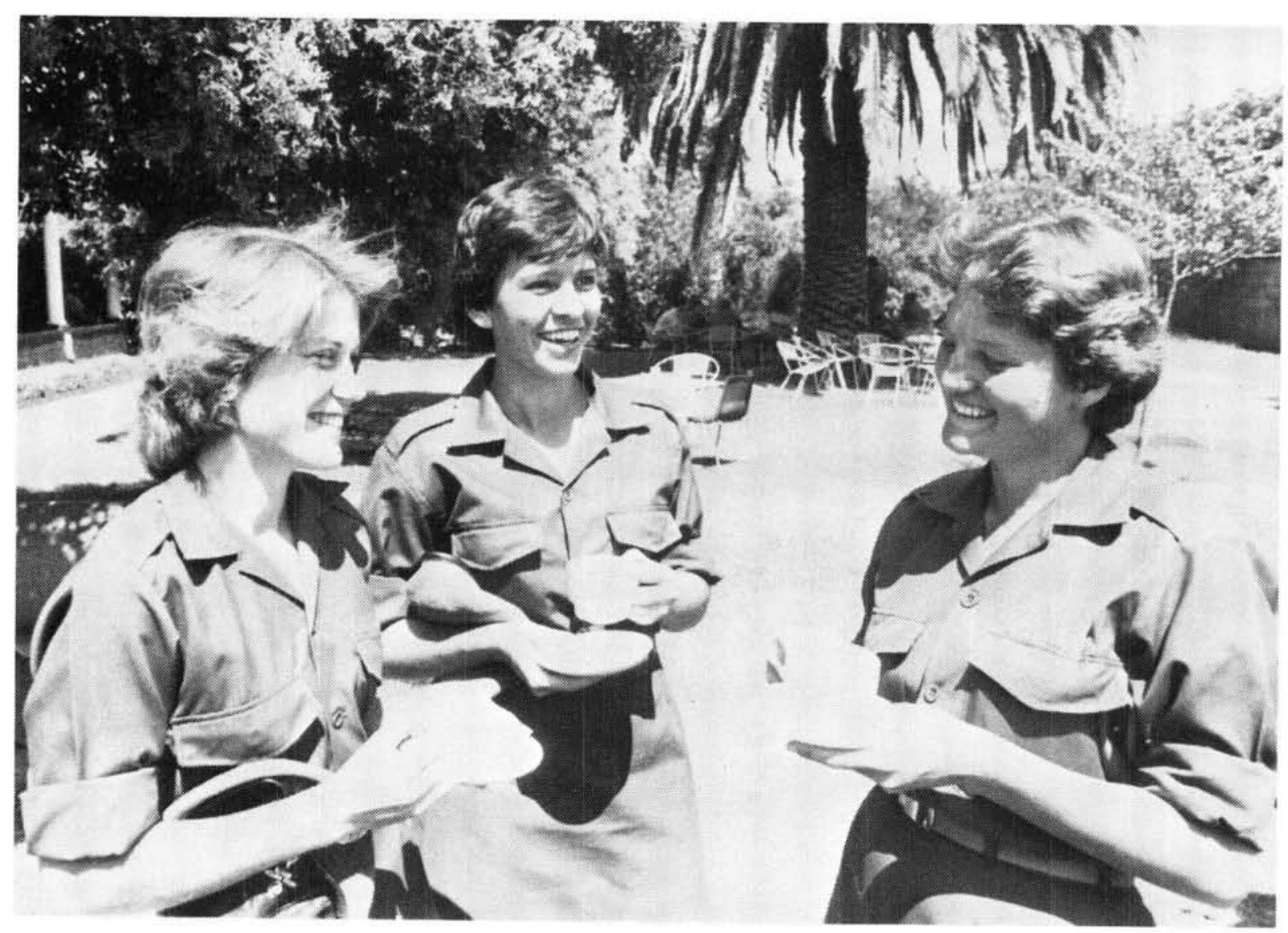

Studente van die SA Leërvrouekollege ontspan tussen lesings 
trum begin met die opleiding van die eerste groep ongetroude vroulike vrywilligers, almal onder die ouderdom van 22 jaar.

\section{Ondersoeke na die vrou in die SA Weermag}

Die ondersoek na die aanwending van die vrou in die Weermag het nie met die Mossop-verslag geëindig nie, maar is verder gevoer deur die Boshoff-en Geldenhuys verslae in 1973 en 1975 respektiewelik, sowel as die Kok-verslag in 1982.

Die Boshoff-verslag het aanbeveel dat vroue in die Staande Mag in verskeie kategorieë poste in diens geneem word. Twee jaar later het die Geldenhuys verslag bevind dat vroue in ' $n$ breë spektrum in die Staande Mag aangewend kan word. Die kategorie van beskikbare poste vir die vrou was ondersteunend, operasioneel staties en dit waarvoor besondere fisiese krag nie vir die uitvoering van die taak vereis is nie. Die Kokverslag het gesonde differensiasie en die ontwikkeling van ' $n$ eiesoortige vrouemilitarisme geloods.

\section{Aanwending in weermagsdele}

Tans maak vroue $10 \%$ van die Staande Mag uit en word sy in 65 verskillende beroepsrigtings aangewend. Beroepsrigtings waarin Leërvroue oor die algemeen aangetref word, is die Personeeldienskorps, Finansiële dienskorps, Bevoorrading, Inligting, Telekommunikasie en in die Militêre Polisie. Alhoewel vroue in die Leër nie in vegtende korpse aangetref word nie, word hulle tog as instrukteurs op wapenstelsels by sommige vegtende eenhede gebruik $\mathrm{nl}$ in die Pantser-, Artillerie- en Lugafweerkorpse en in die SA Infanterie as berede instrukteurs.

Die grootste groep vroue word in die Geneeskundige Diens aangetref oa in professionele beroepe soos tandartse, dokters, verpleegsters, maatskaplike werkers, dieëtkundiges, fisioterapeute en sielkundiges. Hierna volg vroue in die Leër, dan in die Lugmag met die Vlootvroue as die kleinste groep.

Lugmagvroue word in 'n verskeidenheid loopbane aangetref oa die van vlugbeheerder, operasionele inligtingsklerke, lugmagpolisie, tegniese klerke, radarbediener, telekommunikasieoperatrises en as lugwaardinne. In die Lugmag is alle poste vir die vrou toeganklik behalwe die van vlieënier, navigator, tegnikus en laaimeester (Staande Mag).

Vroue in die Vloot word hoofsaaklik administratief en in soortgelyke poste as in die Lugmag aangewend. Vlootvroue word egter nie op skepe aangewend nie, aangesien daar geen fasiliteite vir hulle is nie. Dit word nie verwag dat vroue in die afsienbare toekoms op skepe sal dien nie.

\section{Opleiding}

Die hanteringsbeleid vir vroue in die Weermag bepaal dat opleiding funksioneel moet wees met haar aanwendingsveld in gedagte. Van die aanpassings wat in die opleidingsprogram gemaak word, is dié tov fisiese vereistes. Liggaamlike oefeninge van die vrou het fiksheid, slankheid en soepelheid as doelwit in teenstelling met veggereedheid by die manlike lid waarvoor hy kragoefeninge moet doen. Aangesien vroue nie in die gevegsituasie aangewend word nie, is wapenopleiding slegs op selfverdediging gemik.

Hoewel basiese opleiding van die vrou eiesoortig en afsonderlik van die man is, vind die offisiersopleiding gesamentlik plaas. Drilregulasies vir die vrou is aangepas en vroue dril nie soos mans nie, maar wel saam met hulle. Afgesien van die andersheid van die opleiding vir die vroue, moet sy dieselfde standaard as die man handhaaf om te slaag.

\section{Houdings en gesindhede}

Die rol van soldaat is tradisioneel deur die man vervul en vir die militêr sowel as 'n groot deel van die gemeenskap was dit aanvanklik moeilik om die vrou in dié rol te aanvaar. Verder het daar geen gesindheidsbeïnvloeding plaasgevind voordat die vrou uniform aangetrek het nie. Sy het haar skielik in 'n organisasie bevind wat nog nie tot haar inskakeling georiënteerd was nie.

Tog het die vrou ver gevorder in die 15 jaar wat sy in die Weermag is en staan sy haar plek op talle terreine vol. Volgens brig Lets Kok, tans die enigste vroue-brigadier in die Weermag, speel die vrou vandag ' $n$ beduidende rol in die Weermag en word dit as sodanig deur die man erken. Die professionele vrou ondervind nie veel teenstand van haar manlike kollegas nie aangèsien sy geëvalueer word op grond van haar doeltreffendheid in die pos wat sy beklee, aldus kol Joy Roux. 


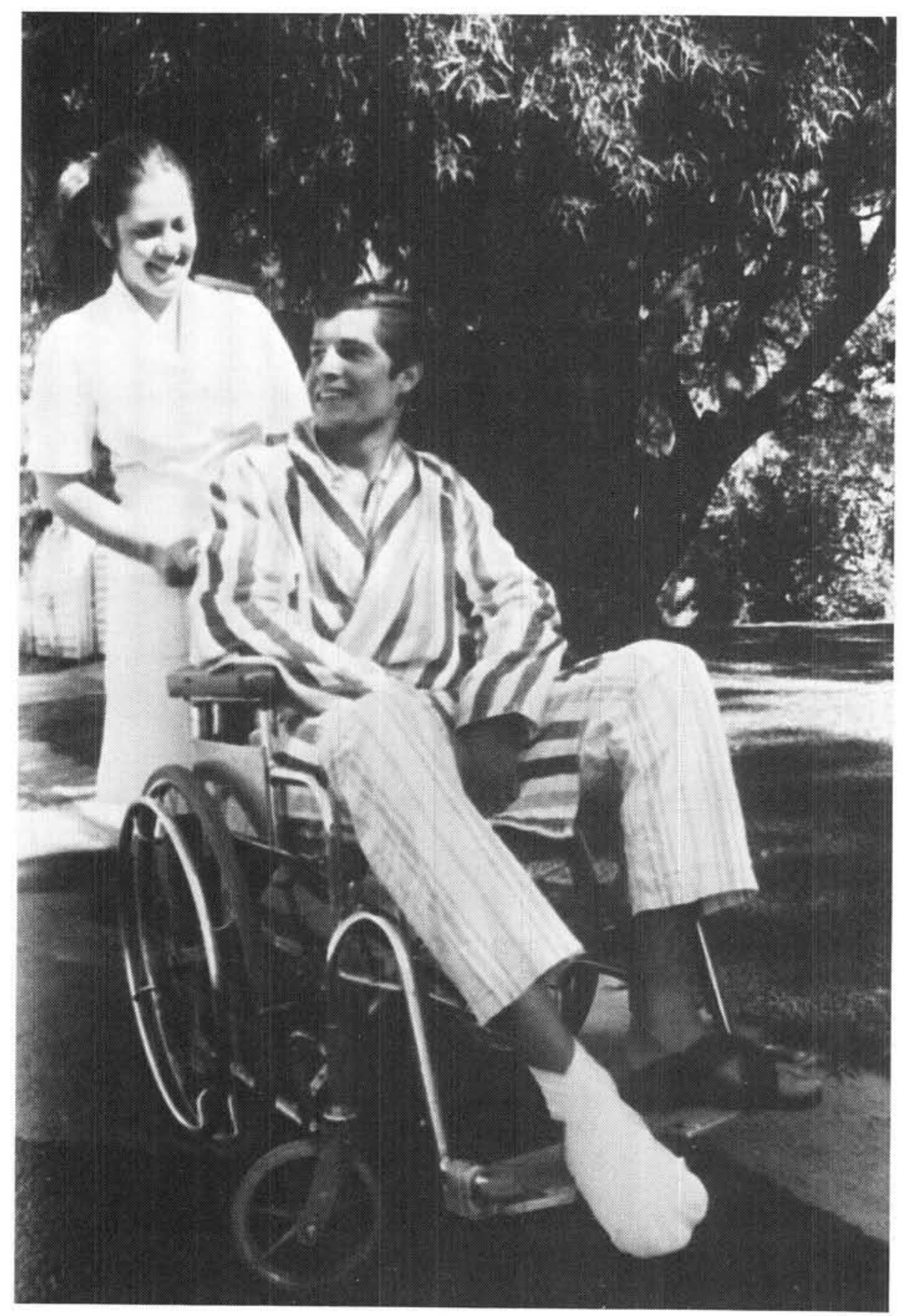

'n Verpleegster van die Militêre Hospitaal besig met nasorg van 'n beseerde soldaat

Met die verandering van die funksie en beeld van die vrou in uniform elders, het dit hier te lande ook by die eise van die tyd aangepas. Die benadering van die SA Weermag tans is dat die vrou se rol hoewel andersoortig, tog net so belangrik as die van die man is. Die militêre beeld moet nie onvoorwaardelik deur die vrou nagestreef word nie, terwyl sy haar eie vroulike identiteit steeds moet behou. Die vrouelid betree 'n tradisionele manswêreld waarin aanpassings gemaak moet word om suksesvol by die Weermag in te skakel. Belangrik om op te let is dat vroue in die Weermag tot nie-vegtende eenhede beperk word.

\section{Aanpassing - uitdagings en probleme}

Die aanvaarding van die vrou in uniform gaan hand aan hand met die mate waarin sy as lid van die Weermagsfamilie inskakel en aanpas. "Met die uitbeweeg van die vrou uit haar tradisionele rol as vrou en moeder wend sy haar tot die Weermag om so haarself in ' $n$ andersoortige 


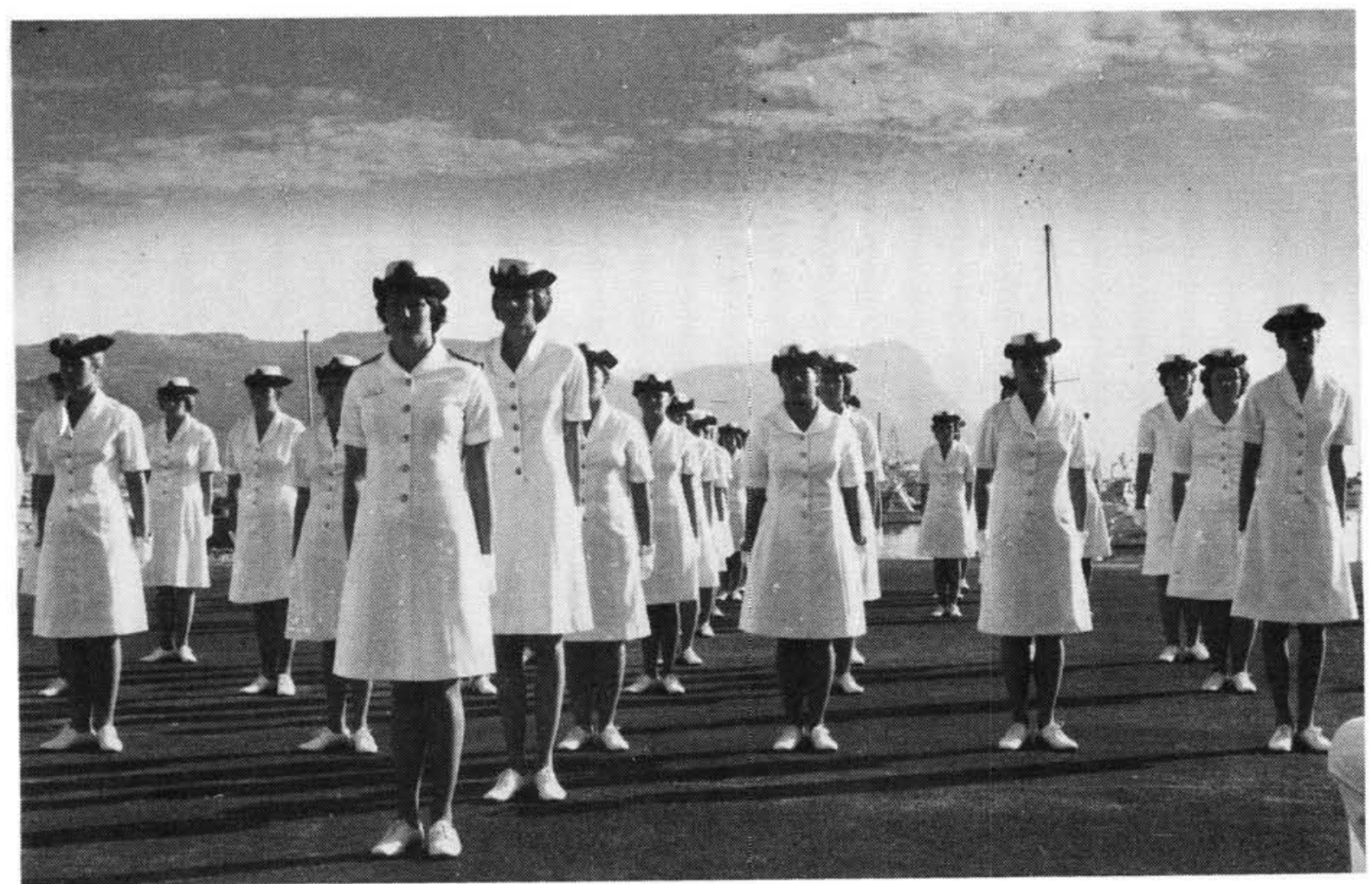

Uitpasseringsparade van Vlootvroue na basiese opleiding

beroepsveld te bewys", aldus kol Roux, SSO Maatskaplike Diens. Brig Kok, Direkteur Vroue, gee 'n byna soortgelyke verklaring waarom vroue by die Weermag aansluit: "om ' $n$ vrou in uniform te wees, beteken opwinding en werksbevrediging en haar aanwending is versoenbaar met vrou-wees."

Hoewel die dra van uniform op sigself vir die vrou ' $n$ aanpassing is om te maak, is dit funksioneel, aldus kmdt Marie van der Walt, SSO Mannekrag, Vroue SA Leër, om haar met die Weermagsorganisasie te identifiseer en neergelegde reëls te aanvaar.

Kol Monica Muller, 'n Senior Stafoffisier in die SA Leër, meen dat die vrou haar goed aanpas by die Weermag wat 'n nuwe werksituasie met 'n definitiewe kultuur en tradisie is. Tog hou nie alle vroue met hul Weermagsloopbane vol nie en die grootste omset is gewoonlik in die eerste drie diensjare.

Van die vrou word verwag om haar militêre loopbaan te kombineer met haar vrou-en-moeder rol. Haar huislike omstandighede en gesinsverpligtinge moet onder beheer wees alvorens sy in die Weermag aanvaar word. Kol Roux wys daarop dat die vrou ' $n$ identiteitskrisis beleef aangaande die mate waarin sy voorkeur aan haar prioriteite moet gee. Is sy eerste soldaat of moeder? Sy

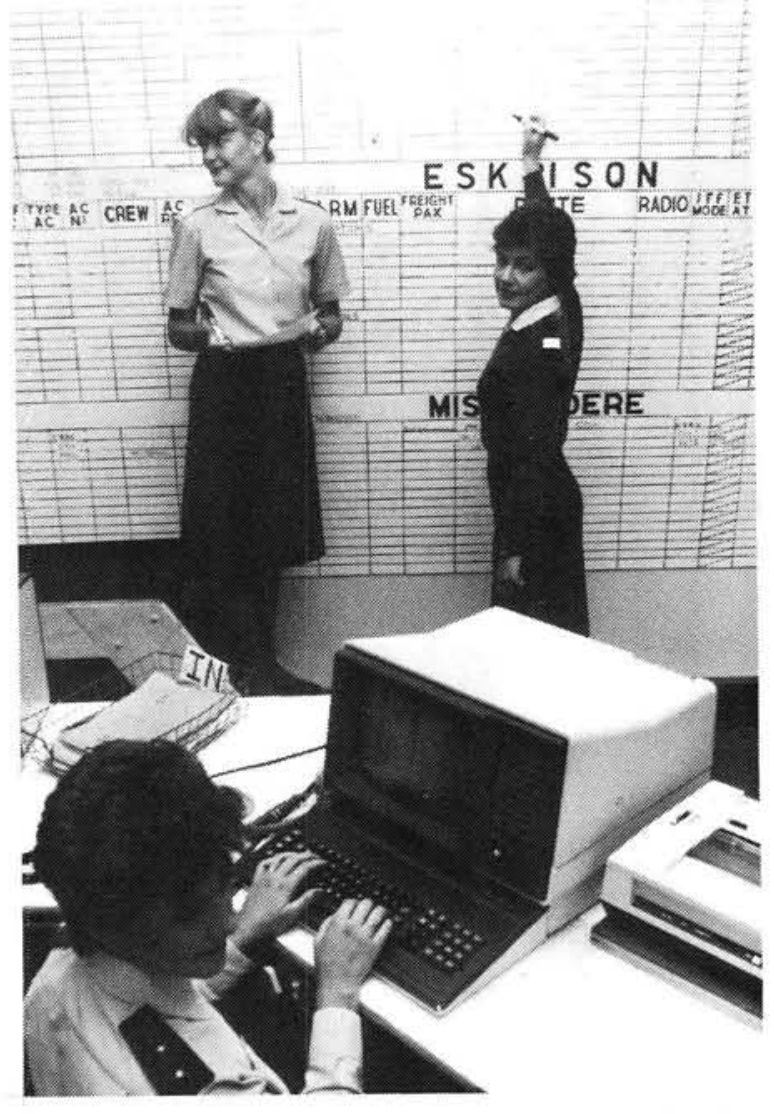

'n Moderne elektroniese beheerde Operasionele Sentrum wat deur Lugmagvroue beman word 
word verplig om vinnig van rolle te verwissel en in voeling met elke rol te bly.

'n Probleem is dat vroue wat weens gesinsverpligtinge gebiedsgebonde is nie altyd ' $n$ verplasing kan aanvaar wat aan bevordering gekoppel is nie. Om die rede kan stagnasie dus intree of as sy voorgeskrewe bevorderingskursusse nie kan bywoon nie, aldus kol Muller. In aansluiting hierby wys kol Roux daarop dat alvorens die vrou verplaas word, daar baie akkommoderend na haar gesinsomstandighede gekyk word.

\section{Die vrou in die geveg}

Sedert die aanwending van vroue in die sewentigerjare is dit Weermagsbeleid dat vroue in tyd van oorlog in 'n nie-vegtende hoedanigheid aangewend kan word, maar alleenlik binne die landsgrense

Redes wat aangevoer word waarom sy nie in 'n gevegsrol aangewend word nie, is dat Suid-Afrikaners nie gereed is vir die vegtende vrou en alles wat daardeur geïmpliseer word. Dit is vir die man moeilik om die vrou in die geveg te

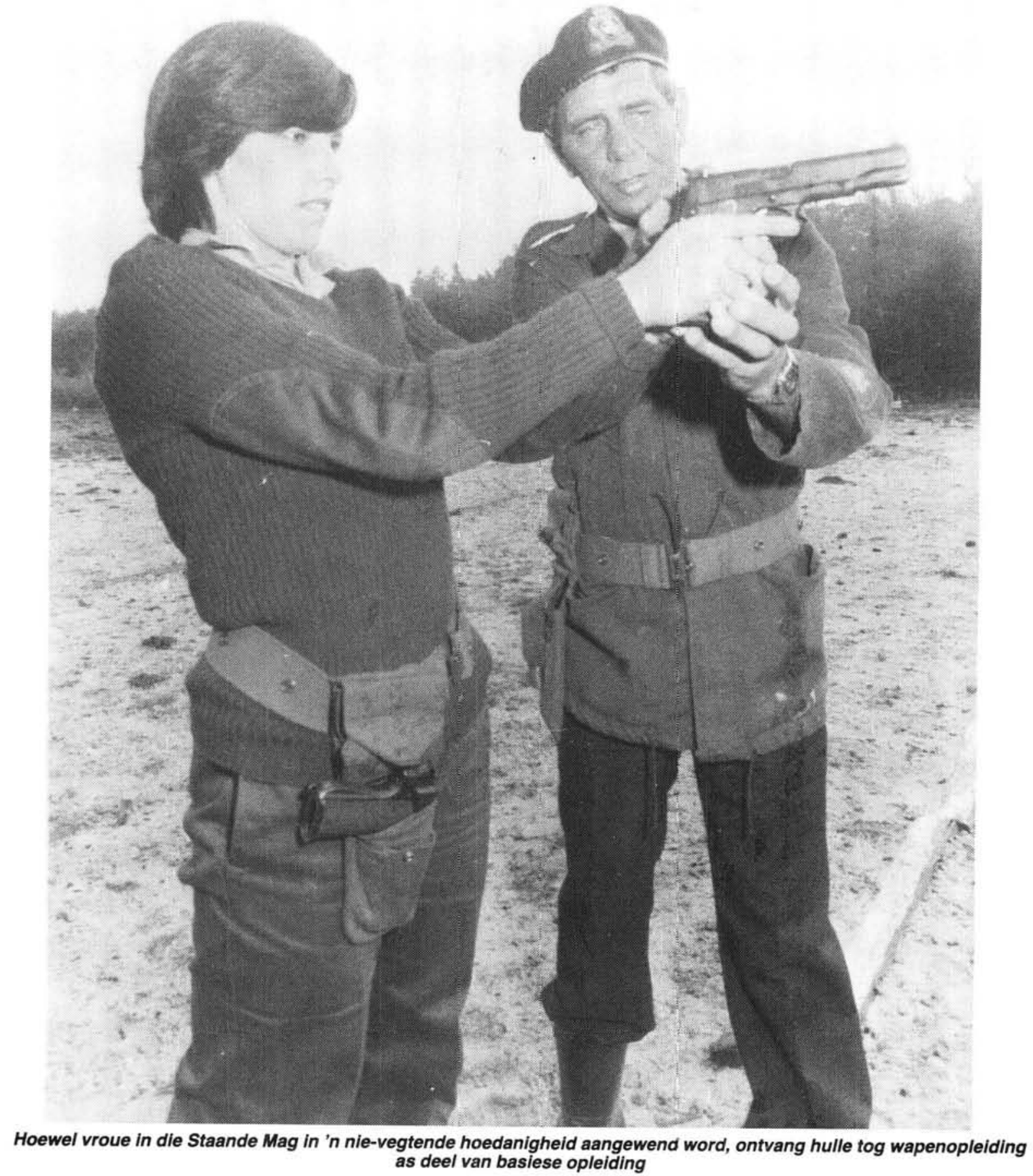


aanvaar, aangesien hy nog altyd 'n beskermende rol teenoor haar ingeneem het en sy kultureel as motiveerder, moreelbouer en die gewer van lewe beskou is. Die blote moontlikheid dat die vrou gewond of krygsgevangene geneem kan word, het 'n negatiewe invloed op die man se effektiwiteit op die oorlogsfront.

Die gevegsbeperking word dus nie deur die Weermag op die vrou geplaas nie, maar deur die meerderheid van die gemeenskap. Die werklike vegtende soldaat is hoofsaaklik die Dienspligtige waarby Burgermag- en Kommandolede ingesluit word. As ons dus praat van die vrou as vegtende soldaat impliseer dit in werklikheid 'n dienspligstelsel vir vroue.

\section{Diensplig vir vroue}

Sedert 1965 het verskeie kommissies van ondersoek die aanwending van die vrou in die Weermag onder die vergrootglas geneem. Die instelling van nasionale diensplig vir vroue al dan nie was 'n onderwerp waaroor telkens uitspraak gegee is.

Die Mossop-verslag van 1965 het diensplig vir vroue summier afgekeur op grond van die skerp politieke reaksie wat dit sou uitlok. Hierteenoor is daar 8 jaar later deur die Boshoff-verslag aanbeveel dat diensplig vir vroue op vrywillige basis op korttermyn noodsaaklik is in die lig van die erns van die landsituasie.

Diensplig vir vroue is twee jaar later deur die Geldenhuys-verslag afgewys, omrede dit as onmoontlik beskou is en die stelsel sou nie in die nabye toekoms oorweeg word nie. Teen 1979 was die klimaat by die Suid-Afrikaanse publiek steeds nie gunstig vir nasionale diensplig vir vroue nie. Vervolgens is daar deur die Opmanverslag beslis om die stelsel van diensplig vir vroue as aanvullend tot nasionale diensplig vir jongmans te sien. Vroue sou nie gebruik word as daar genoeg mans beskikbaar is nie. Tog word 'n stelsel van vrywillige militêre diensplig vir vroue aanbeveel. Vroue wat 'n bydrae wil lewer tot landsverdediging en militêr paraat wil wees, sal in so 'n stelsel hul deel kan bydra en bykomende mannekrag beskikbaar stel.

In 1980 tydens die 71 ste jaarkongres van die Suid-Afrikaanse Vrouefederasie is ' $n$ beskrywingspunt ten gunste van diensplig vir vroue aanvaar. As dit van die Suid-Afrikaanse Vrouefederasie afhang, sal elke Suid-Afrikaanse meisie verpligte militêre opleiding ontvang nadat sy skool verlaat het. Daar is gewys op die tekort aan verpleegpersoneel by hospitale en tehuise vir bejaardes en klinieke wat op die wyse verlig kan word.

Uiteenlopende en gemengde reaksies uit alle oorde het oor die aangeleentheid opgeklink. Reaksies uit die geledere van vroue was oor die algemeen positief en gunstig en dit was vir hulle om't ewe of vroue in die gewapende magte of in die hulpdienste moes dien. Daar was diegene wat nie ten gunste was van verpligte militêre opleiding nie, maar wel dat meisies vir vrywillige burgermagopleiding moes aanmeld.

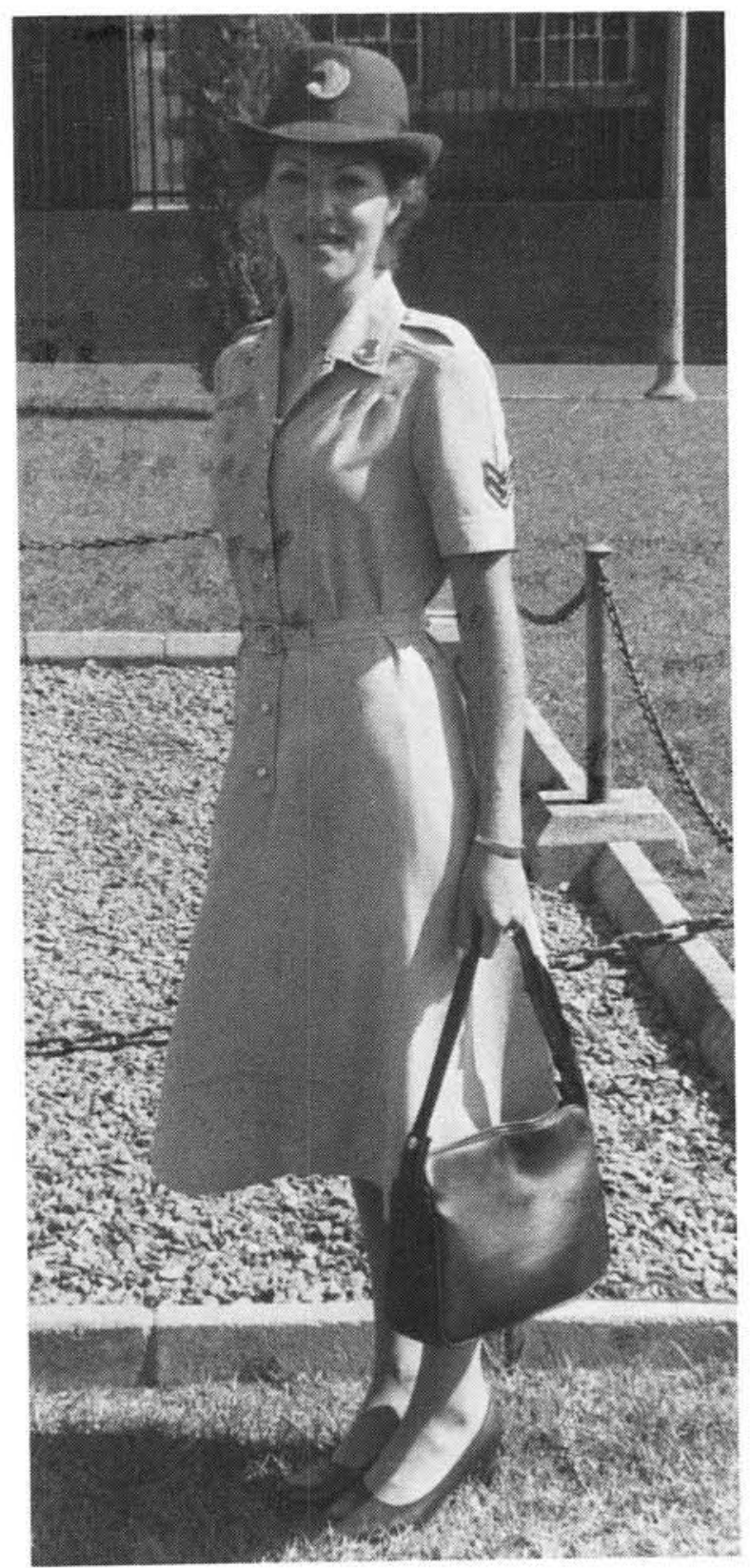

Die verbeterde uniform vir leërvroue wat in 1985 uitgereik is 
'n Algemene beswaar was dat die standaard van die verpleegberoep verlaag sou word indien meisies verplig word om verpligte hospitaaldiens te doen. Die tydperk van twee jaar dienspligtigheid was vir die meeste meisies problematies en hulle sou vrywillige diensplig verkies.

Die moontlikheid van diensplig vir vroue is weer opgehaal met die verskyning van die 1982 Witskrif oor Verdediging en Krygstuigvoorsiening wat 'n groter inname van vrywillige vroue dienspligtiges op medium termyn aanbeveel het. Tog sou die Staande Mag eers moes uitbrei om vroue te akkommodeer alvorens ' $n$ grootskaalse uitbreiding kon plaasvind. Aanvullend hierby het die tweede lesing van die Wysingswet op Verdediging die moontlikheid voorgehou om vir ' $n$ lotingstelsel vir blanke vroue voorsiening te maak indien omstandighede dit sou vereis. Die versoek om hiervan af te sien, het van die Weermag self gekom.

Diensplig vir vroue hang dus saam met ' $n$ algehele bewusmaking van die Suid-Afrikaanse publiek tov die veranderende rol van die vrou in die gemeenskap. Alvorens die landsituasie nie sodanige afmetings sou neem dat die Weermag genoodsaak word om van die vrou ter aanvulling van 'n mannekragtekort gebruik te maak nie, sal sy sekerlik nie in die afsienbare toekoms vir diensplig opgeroep word nie.

Alles in ag geneem, het die vrou in uniform gekom om te bly. In Noord-Amerika was daar in 1982 al 182000 vroue in uniform waarvan sewe generaals is en daar word voorspel dat 250000 vroue in die jaar 2000 in die Amerikaanse Weermag sal dien. In Suid-Afrika maak vrouelede 'n beduidende $10.2 \%$ van die Weermag uit en ver$\mathrm{vul}$ as sodanig ' $\mathrm{n}$ belangrike rol in die verdediging van ons land.

* Lt Kdr E.M. Meyers MA(HOD) is verbonde aan die Militêre Informasieburo, SAW.
Bronne

Boeke

C.M. Bakkes: Die Britse deurbraak aan die Benede Tugela op Majubadag 1900, Sentrale Dokumentasiediens SAW Publikasie № 3 , Pretoria 1973

J. Brandt: Die Kappie Kommando of Boervrouwen in Geheim Dienst, Holländsch-Afrikaanse Uitgevers-Maatskappij, Kaapstad 1915.

W.J. de Kock (red): Dictionary of South African Biography, vol 1, Tafelberg Uitgewers, Kaapstad, 1968.

J.C. Goosen: South Africa's Navy. The first fifty years. W.J. Flesh and Partners, Kaapstad, 1973

Militêre Informasieburo, SAW: Militêre Geneeskunde in Suid-Afrika, Publikasie No 7, Pretoria 1983.

M. Nathan: The Voortrekkers of South Africa, Central News Agency, South Africa, 1937.

Standard Encyclopaedia of South Africa, Tur-Zwe, Vol II, Nassau Ltd.

\section{Tydskrifte}

Die Huisgenoot, Des 1938 (Gedenkuitgawe).

Militaria, 8/2/1978: A.E. van Jaarsveldt: Die Suid-Afrikaanse Militêre Verplegingsdiens.

Militaria, 9/3/1979: C. Bergh: Die Ontstaan van Vrouelugverenigings in Suid-Afrika voor die Tweede Wêreldoorlog.

Militaria, 11/2/1981: E.M. Meyers: Ontwikkeling van die Vrou as soldaat.

Militaria, 13/2/1983: D. Conradie: Achievements of the SADF $1961-1982$.

Nonqqai, April 1944: P.C. Batley: Home-Front Workers.

Paratus, Maart 1982: Then as now our women were doing their duty.

Paratus, April 1982: SA Leërvroue is geen Amasones!

Paratus, Julie 1984: 'n Leërvrou wat respek afdwing.

Paratus, Nov 1981: Diensplig vir meisies - meningsverskil.

SA Panorama: Julie 1983: Sieraad van die Weermag.

\section{Koerante}

Beeld, 3/4/1982: Vroue moet ook help.

Beeld, 26/3/82: Geen diensplig nou vir vroue.

Die Transvaler, 30/3/1983: Vroue speel 'n belangrike rol in landsverdediging.

Burger, 3/4/82: Weermag wil gekleurdes, vroue betrek.

Pretoria News, 3/4/82: Bigger defence role for women.

Rand Daily Mail, 5/10/81: Yes let's get in Step!

\section{Studiestuk}

H.M.J.P. van Zyl: Die aanwending van die Vrou in die SAW, Studiestuk by Universiteit Stellenbosch 15 Mei 1985.

Onderhoude

Onderhoud met brig L. Kok, Direkteur Vroue, op 25 September 1985.

Onderhoude met kol J. Roux, SSO Maatskaplike Diens, op 30 September en 7 Oktober 1985.

Onderhoud met kmdt M. van der Walt, S01 Mannekrag Vroue SA Leër, op 27 September 1985.

Onderhoud met It kdr M. Blackbeard, S01 Vroue Vloot, op 7 Oktober 1985 .

Onderhoud met kapt P. Schilbach, S01 Vroue Lugmag, op 26 September 1985 